\title{
Implementation of Aerial Monitoring Technology in Permanent Grassland Management
}

\author{
George POPESCU, Cosmin Alin POPESCU, Mihai HERBEI*, Lucian DRAGOMIR, Ionel SAMFIRA and Costel \\ BARLIBA
}

Banat's University of Agricultural Sciences and Veterinary Medicine "King Michael I of Romania" from Timisoara, Romania

* corresponding author: mihai.herbei@gmail.com

BulletinUASVM Horticulture 76(2) / 2019

Print ISSN 1843-5254, Electronic ISSN 1843-5394

DOI:10.15835/buasvmcn-hort: 2019.0037

\begin{abstract}
In the last decade, in Romania, the management of large and very diverse agricultural areas from the point of view of the relief has been imposed especially the for the case of permanent grasslands. These ecosystems that are in balance due to the interdependence between the biotic and abiotic factors should be exploited according to correct management practices, supervised so that their level of production and quality should not be damaged. With the help of computer systems, the management and exploitation plan was established for 10-year periods corresponding to the period of renting these areas to livestock breeders. The present study aims at using the aerial monitoring with drone systems, the aerial surveillance of the correct implementation of management practices contractually assumed by the users and the breeders respectively. Thus, it is analyzed the quadratic processing of the surfaces, the compliance with the limits of rented areas, the observance of the load with animals per hectare (livestock unit LU) as well as of other management elements imported for maintaining and improving the condition of the permanent grasslands of Romania.
\end{abstract}

Keywords: cadastre, drone, orthophotoplan, Phantom 4, permanent pastures

\section{Introduction}

With the integration of Romania into the European Union and the implantation of the system of surface or animal subsidy, in agricultural practice it was imposed the management of large and very different surfaces from those of the cadastral practice. In the management of the agricultural heritage of Romania, the administration of the pastoral fund of about 5 million hectares is distinguished along with the pasture breeding, representing areas of major interest in the national economy (Samfira et al., 2011). The management design as well as the monitoring of its implementation in time on the practical surfaces includes the use of modern technologies of territory management but especially aerial monitoring through drone systems.
It was considered the design of a modern management of the use of permeable grasslands in the western part of Romania and especially the monitoring of its use with animals. It was desired to create an interdependence between the cadastral organization of the territory and the extraction of as much descriptive information by air flight with drone equipment as possible.

The image analysis drew the management design for a period of 10 years according to the methodology in force in Romania (Law 165/2013; OG 44/2013; Law 44/2018; Law of Zootechnics 2019). After establishing the management practice for a period of 10 years using the large-scale information generated by the drone system, it was desired to design a monitoring system (Dragomir and Herbei, 2012) for the implementation of the 
management (Herbei et al., 2016). These systems are required as a control tool by the owner of the land, most of the times the Romanian state in relation to the animal breeders who rent these surfaces for long term.

\section{Materials and methods}

The biological material was represented by the permanent vegetal associations specific to a reduced altitudinal deviation from the Western Plain of Romania in the form of permanent grasslands (Govedarica et al., 2015). The management design for an area of 630 hectares of permanent grassland was realized starting from the cadastral organization of the territory generated by Law 165/2013 (Popescu, 2015) at the level of the Denta Administrative Teritorial Unit (ATU), Timis county (Fig.1).

In this context, with the help of the drone flight, detailed information on the state of the land and the works required during the rental period were extracted. The implementation of the projected management is very difficult to follow for traditional procedures, especially in the case of large areas or with difficult terrain.

For the management design, namely the cadastral organization of the territory, the technique of processing the data taken from ortho-

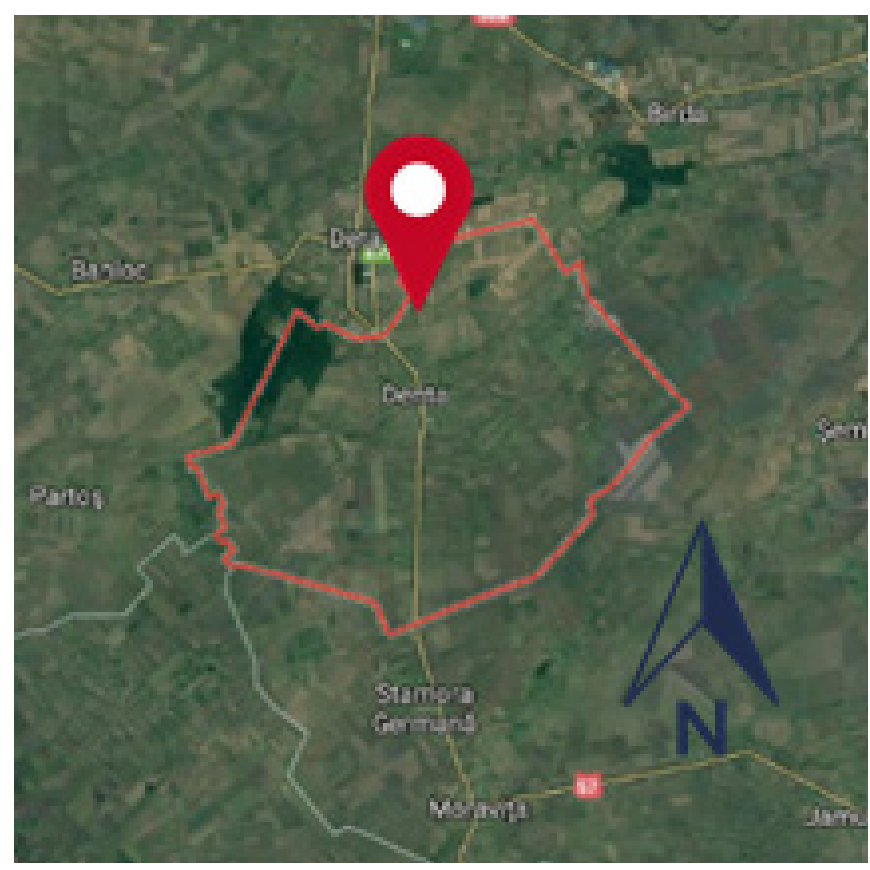

Figure 1. Localization of Denta ATU, Timis county

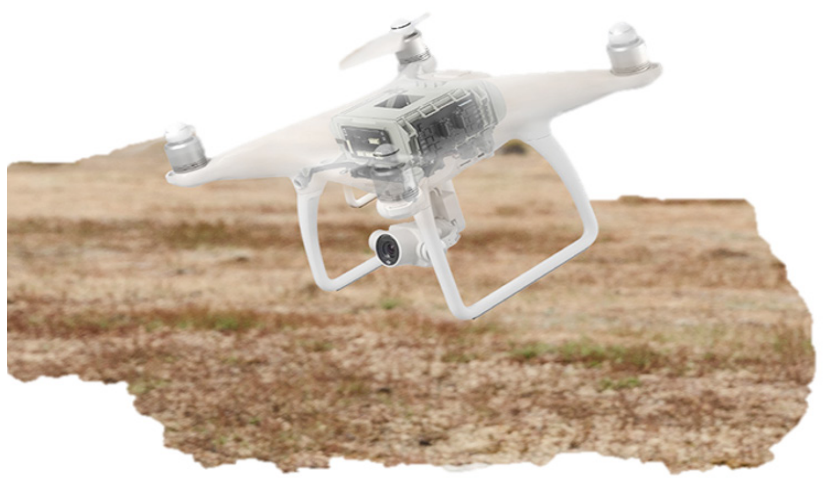

Figure 2. UAV - Phantom 4 Pro 


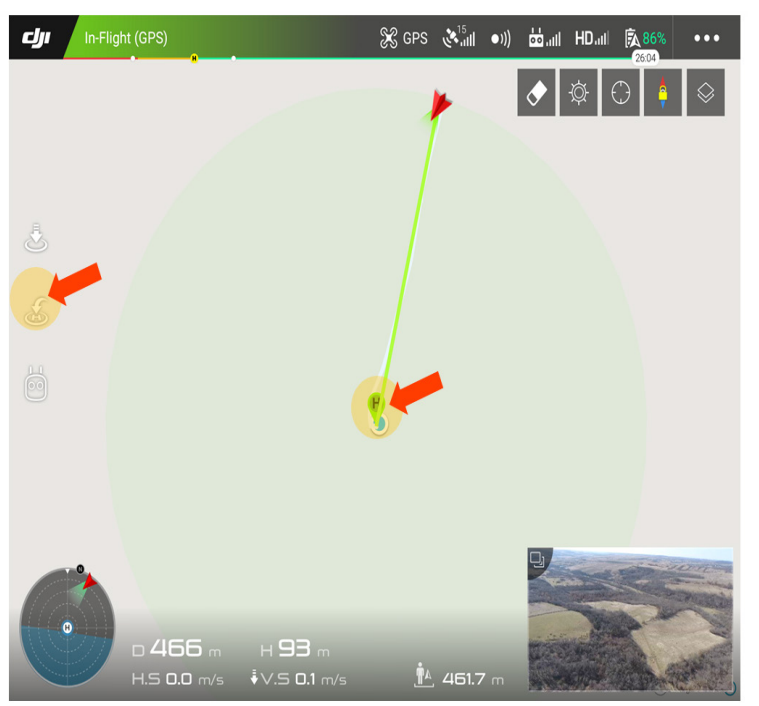

Figure 3. UAV Phantom 4 Pro - drift characteristics of the IMU - maximum flight range

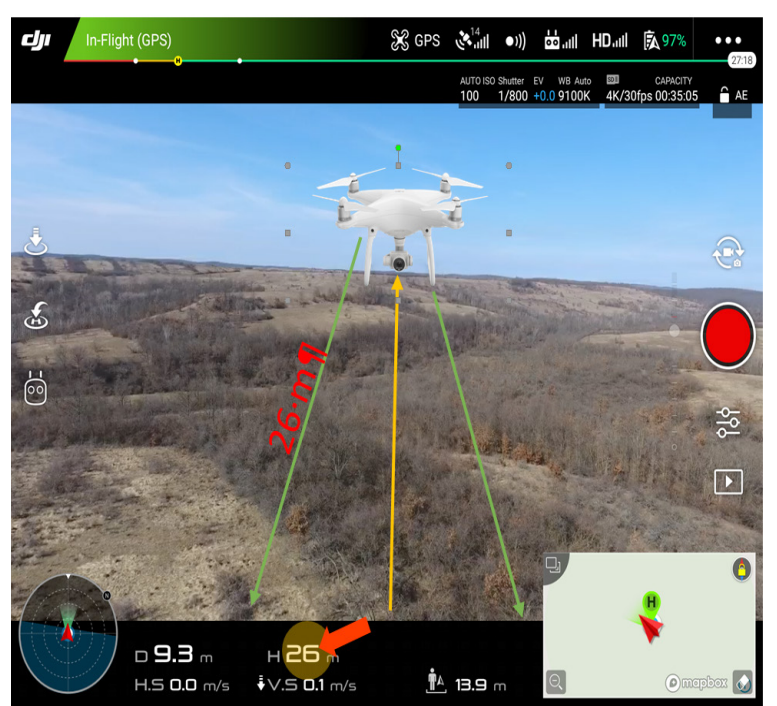

Figure 4. UAV Phantom 4 Pro - drift characteristics of the IMU - altitude

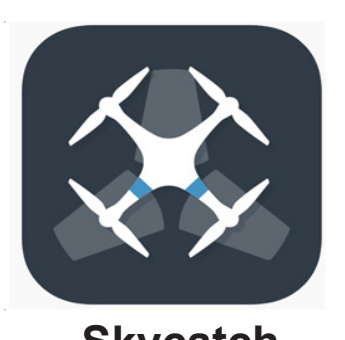

Skycatch

Figure 5. Skycatch - software

photoplan images was used. The large-scale descriptive analysis was performed by Phantom 4 drone aerial flight followed by data processing using specific software (Smuleac et al., 2018).

Platform UAV used in the current context is a Phantom 4 Pro model (Fig. 2), extremely intelligent with flight capabilities, being able to track objects without the need for other devices, all while shooting at a $4 \mathrm{~K}$ resolution at a frame-maximum rates of 30 frames per second or 12 megapixel photos. The Vision Positioning System allows the flight to be performed with high precision when flying indoors or when the GPS/GLONASS system is not available.

For completing the stages of the study flight, we considered several aspects and, as a general presentation, each project can be divided into three stages, namely:

- flight planning;
- the basic study that included the flight, as well as the collection of reference data from the field; - processing of the data taken.

Taking into account the drift characteristics of the IMU (Fig. 3) for the flight apparatus, the maximum length of a flight line must not exceed $800 \div 1000 \mathrm{~m}$ (based on the chosen flight speed). Flight planning is directly controlled by the specific software. The main objective is that the study area be covered by parallel flight lines, including some overlap between consecutive lines (Fig. 6).

At the same time, the software Skycatch (Fig. 4) used for flight planning allows the integration into the system of a digital model for the terrain in the study area.

With a constant flight altitude, depending on the height of the ground, the bandwidth varies and the strip may become too narrow for complete coverage if the terrain changes. In order to avoid 


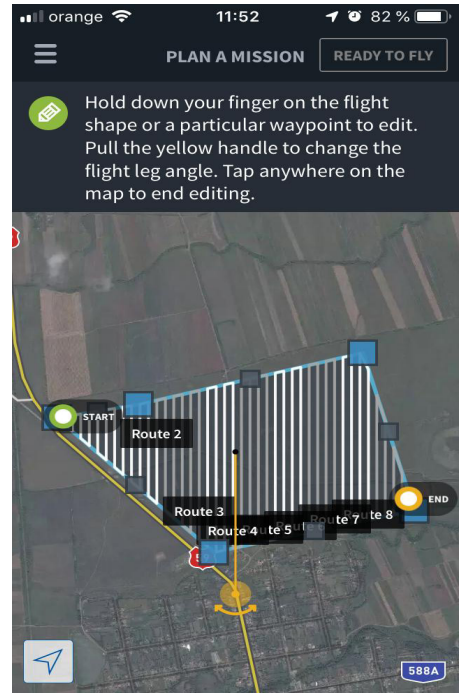

Figure 6. The area of interest, the flight lines in the optimal direction

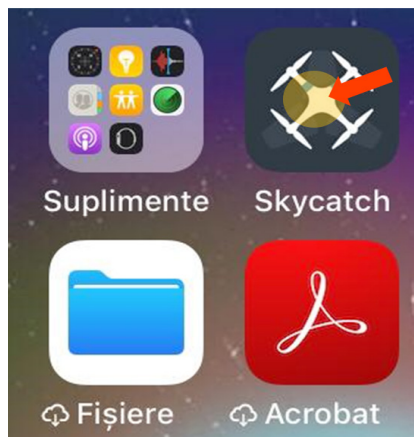

Figure 7. Skycatch app - smarthphone

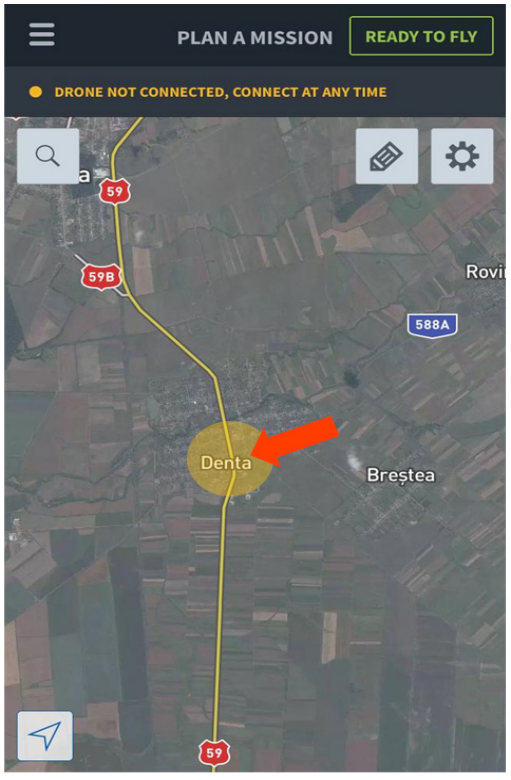

Figure 8. Location of the study area

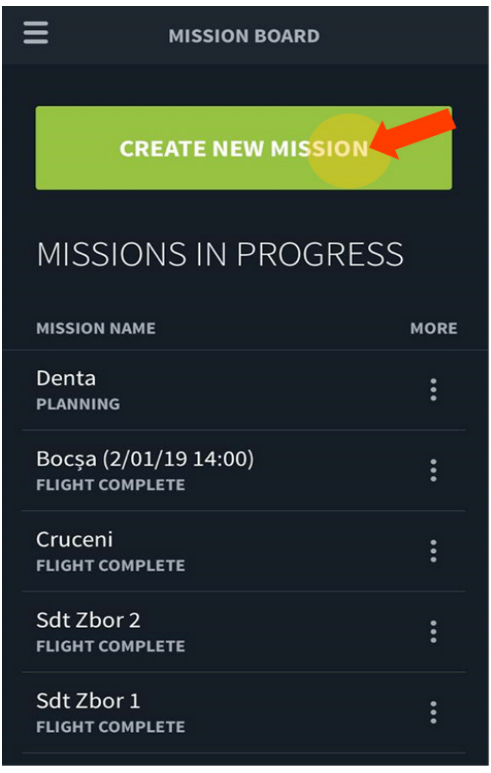

Figure 9. Creating the mission 
shortcomings in coverage, the planning of the flight lines should be done over an orthophotomap, noticing a considerable increase in the reliability and efficiency of the planning (Fig. 6). The flight plan is subsequently stored and transferred to the aircraft management and guidance system.

It is absolutely necessary to select the reference points and to draw the flight paths in relation to the topography of the area. The main steps involved in creating the flight plan and collecting the data from the field are the following:
- The Skycatch app opens on your tablet or smartphone (Fig. 7);

- A new mission is created with the name of the study area. In our case being the locality Denta, Timiș (Fig. 8, 9);

- Press (click) on the newly created mission (Fig. 9), then select the drawing option on the orthophotomap, with a continuous press on the device screen to start drawing the area (Fig. 11).

The modification of the study area is made by pressing continuously on the outline already created (Fig. 14, 15).

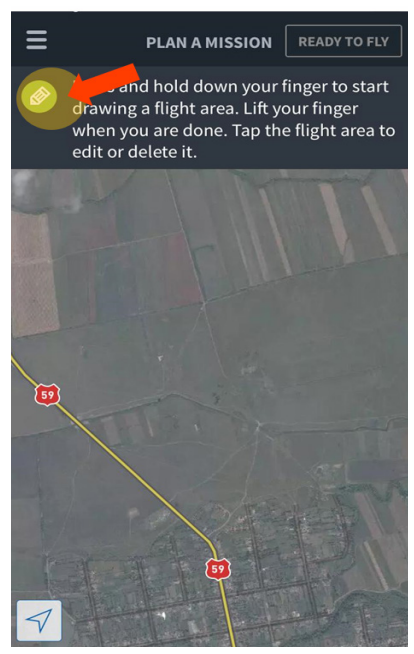

Figure10. Location of the study area

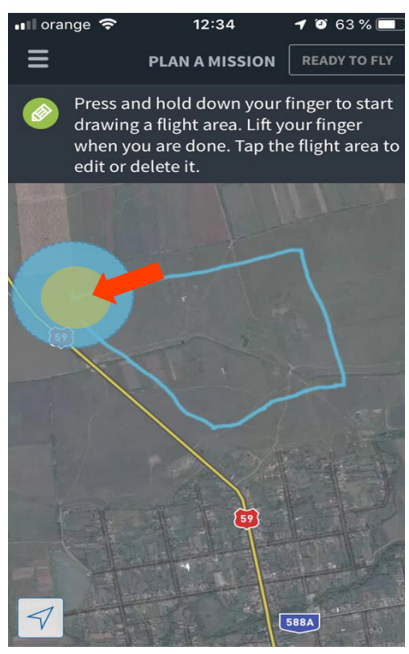

Figure 11. Drawing the flight corridor

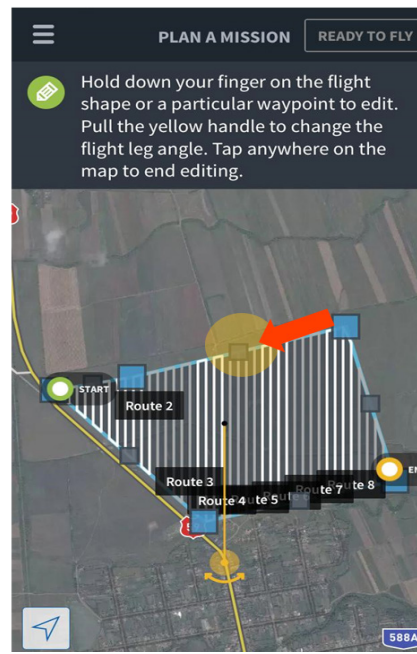

Figure 12. The newly created flight corridor

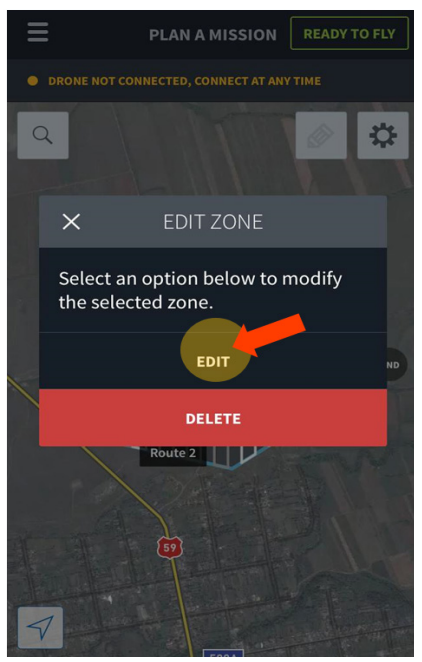

Figure 13. Editing the flight corridor

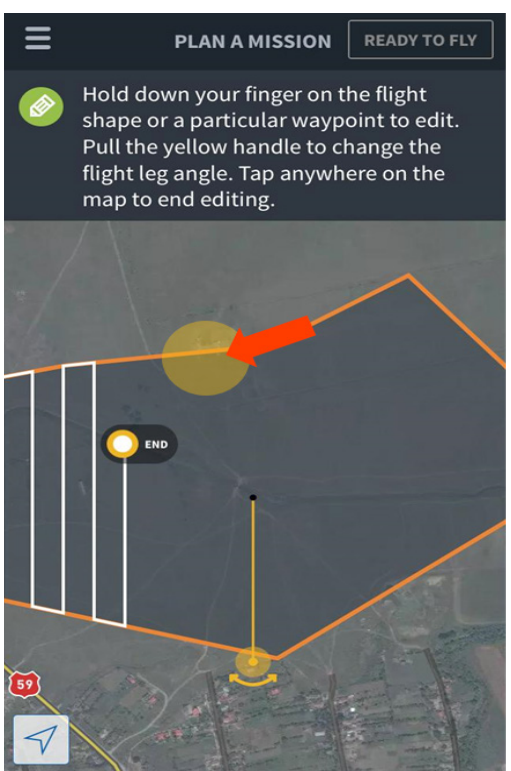

Figure 14. Procedure to change the area

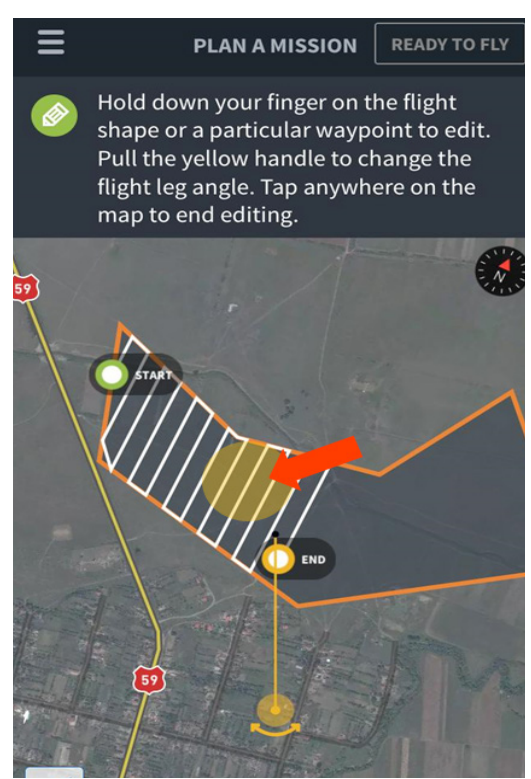

Figure 15. The area being modified 
With the contour of the defined study area and the pre-flight stages, the drone is ready for the studio flight (Fig. 16).

The process of collecting data from the field begins when the option - READY TO FLY - is activated (Fig. 17).

The study flight aims to collect data according to the previously configured flight plan. For the study mission, the ideal time depends on the requirements of the project (with or without vegetation, without snow, etc.), as well as on the weather conditions, which must be favorable (without wind, rain or storms, fog, etc.).

\section{Results and discussion}

After the area monitoring process was completed, using the drone-type aerial monitoring system, it was necessary to process the images obtained using the Count Things software (Fig. 19), to determine density of animals (Fig. 18) for one of the areas taken in study (Denta, Timis).

In this context the successfully used specific functions of the drone-type flight are exploited, namely: the control of respecting the limits of rented surfaces, the observance of the animal load per hectare, the observance of the grazing time, performing the improvement works of the natural grasslands assumed by contract by the breeders.

The application of the aerial flight system with the drone consists in the supervision of the observance for the entire duration of the animals density, in our case, the loading of sheep for the locality Rovinita Mare (Fig. 23), with a number of 309 sheep/0.256 ha, established as being optimal

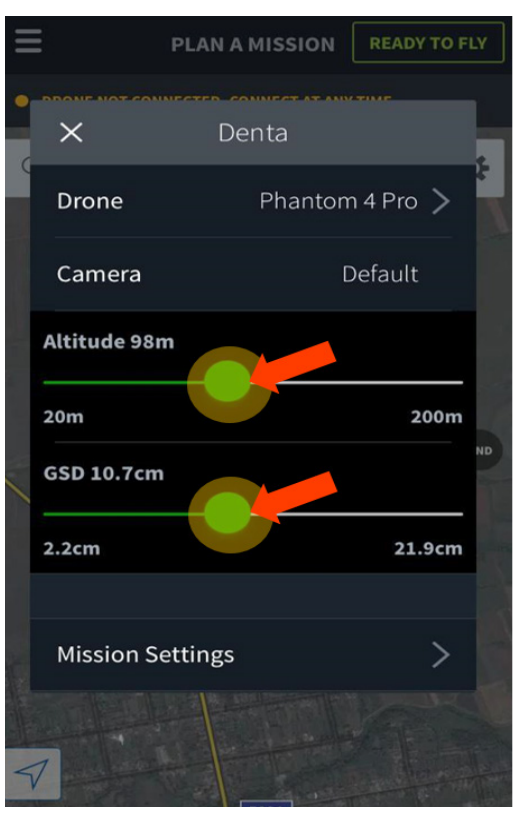

Figure 16. Definition of flight parameters

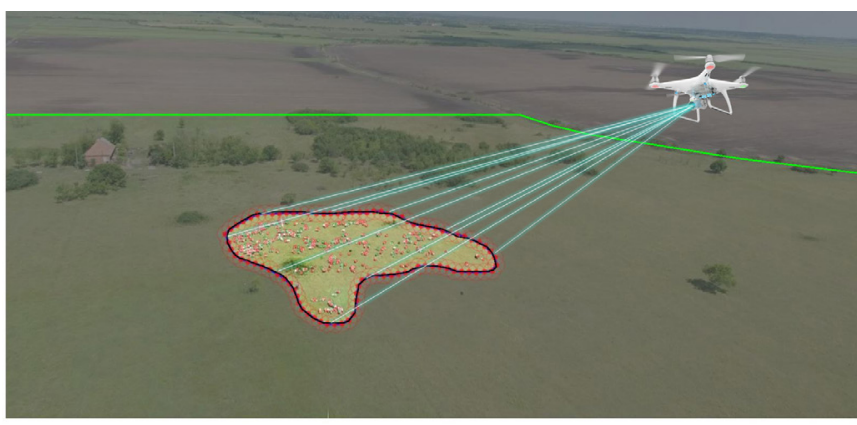

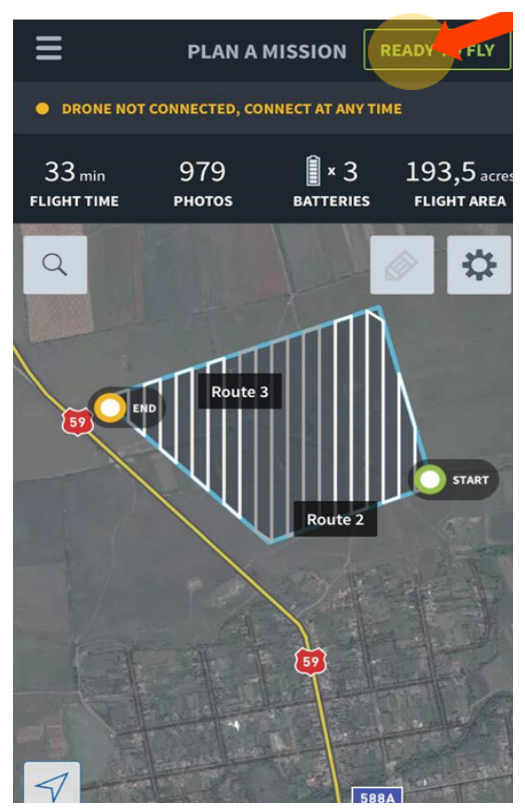

Figure 17. Complete mission - flight ready

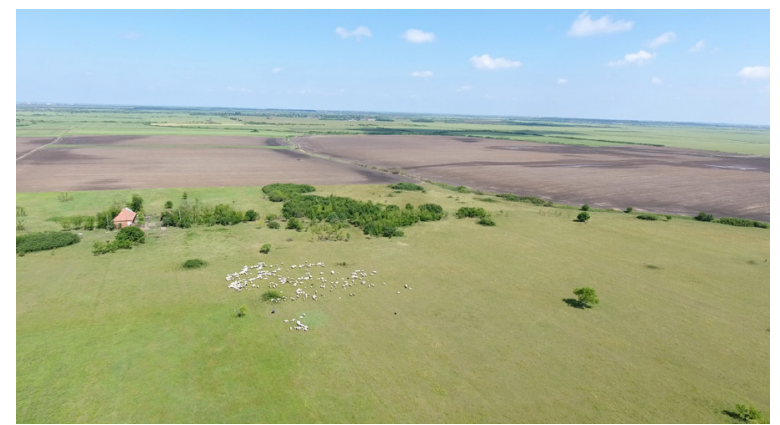

Figure 18. Monitoring scheme for density of animals - Rovinita Mare 

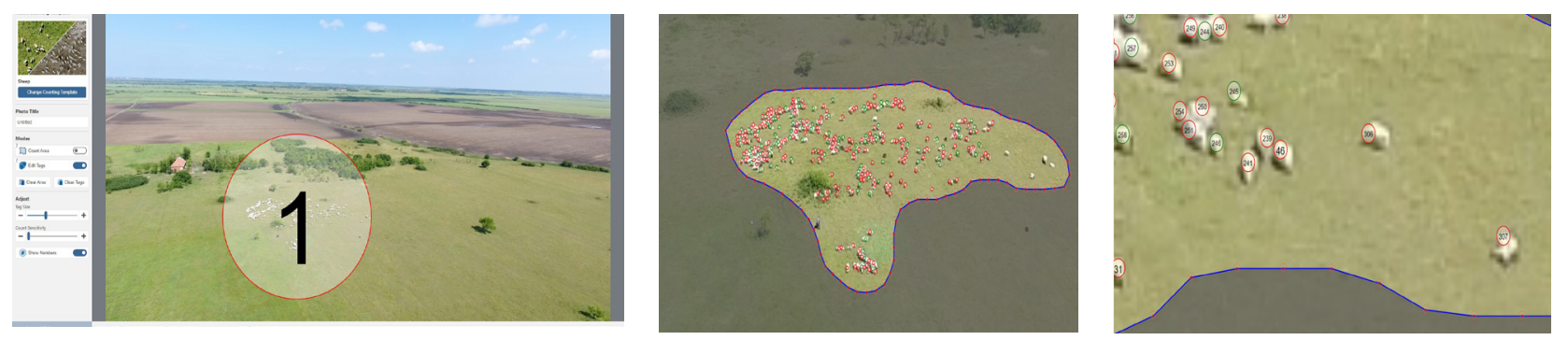

Figure 19. Image processing using Count Things software

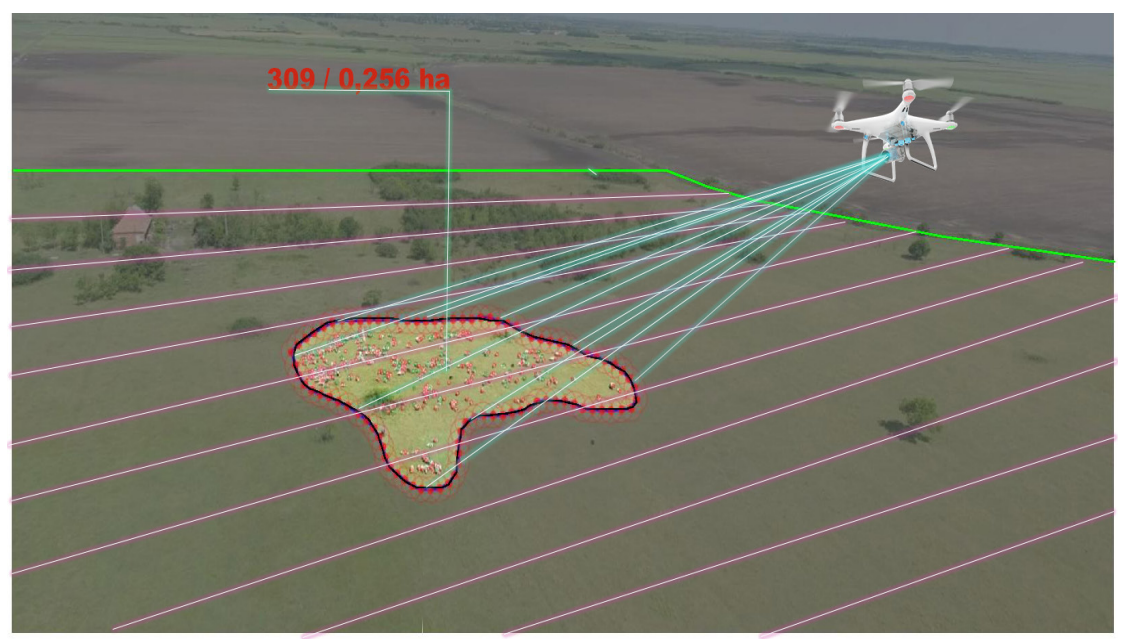

Figure 20. Determining the number of sheep by the COUNT function

over the entire grazing time settled, customized by each management plan (Fig. 20).

The image analysis drew the management design for a period of 10 years according to the methodology in force in Romania like Law $165 / 2013$ with a special part for pastures. The monitoring system design for the implementation of the management started from the electronics maps generated at Law 165/2013. The management plan for 10 years of these permanent landscaping surfaces in Gataia Plain and Lunca Barzavei belonging to Denta UAT (Fig. 21, 22) started with the cadastral analysis of the area of 630 hectares. Thus, the so-called Operational Unit (UA) of a size below the 100 hectare threshold was generated. The operating limits for each UA have been generated electronically in AutoCAD and will be used later when the surfaces are rented and the usage indicators must be followed.

The design of the management of natural grassland ecosystems also includes important aspects such as: determining the type of permanent vegetable association and its production capacity.
The production capacity is positively correlated with the numbr of animals for one hectare (livestock unit LU), that must be repeated during the implementation of the 10-year management plan. For the present case the grasslands under APIA commitment with the measures 214/1, 214/2 and 214/3.2: grazing is carried out with maximum 1.0 livestock unit (LU) - maximum one bovine per hectare and maximum 0.7 (LU) per hectare (for measure 214/3.1). According to the Law of Zootechnics (2019) it was established that the minimum load per hectare is $0.3 \mathrm{LU} / \mathrm{ha}$.

It is also important to respect the established grazing time so that the permanent natural pasture ecosystem is not damaged. This is because it is the cheapest source for providing herbivore food during the vegetation period, having multiple advantages arising from the favorable effects on both animals and pastures in the soil-plant-animal relationship. In Order no. 544 of June 21, 2013, Art. 6, the following are stipulated: (1) the beginning of the grazing is made according to the pedoclimatic conditions and the degree of development of the 


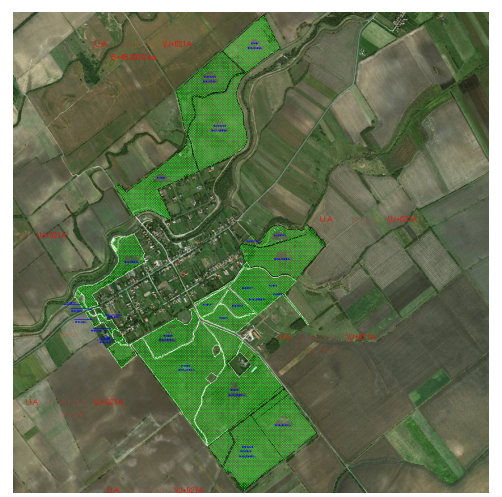

Figure 21. Location of grassland surfaces of the Denta ATU,

Timiș County superimposed on orthophotomap

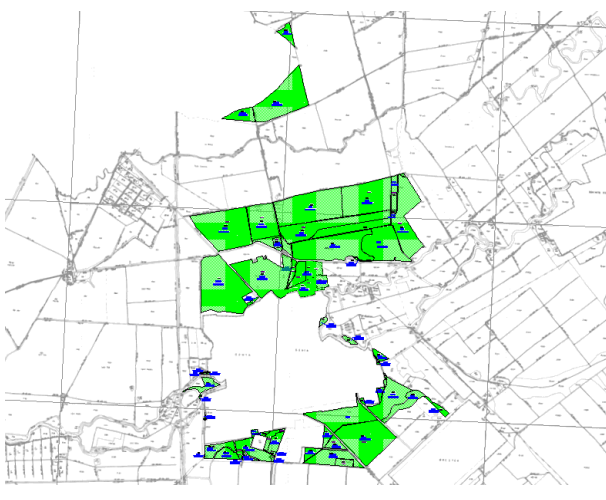

Figure 22. Arrangement of the studied grasslands of Denta ATU on the cadastral map Scale 1: 5,000

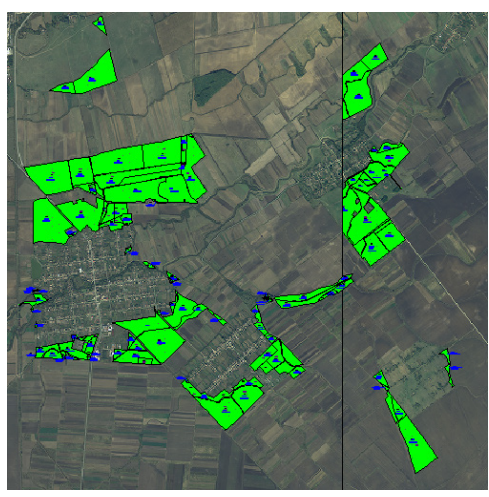

Figure 23. Arrangement of grasslands Rovinița Mare grass carpet; (2) Avoidance of grazing too early, which may affect the period of regeneration, the health and survival of the plants; (3) The grazing period will end in November, at a date established according to the evolution of the temperatures and the precipitation regime; (4) The date of beginning and ending the grazing, as well as the way of organizing the grazing, continuously or by fields, are established by decision of the Local Council.

Taking into account all the characteristics of the local climate, the duration of the grazing season, in the plain area where Denta is located, is about 194 days, from the last decade of April to the end of October.

To the same extent we do not recommend the use of grassland by grazing later than November 1 st. The last grazing should be done at the latest 20 30 days before the installation of the permanent frosts. Thus, the plants have the possibility to accumulate carbohydrates, to restore their vegetative mass, which causes a better tolerance of the frosts on one hand, and on the other hand the early start in vegetation.

The duration of restoration of the vegetation from one grazing cycle to another is about 25-30 days during rainy periods (especially spring and autumn) and 40-45 days during summer under proper maintenance conditions. When dividing the meadow into rows for rational grazing, it is recommended that their surface be established so that the grass on them feeds for 3-5 days the herd of grazing animals, after which the animals are moved to the next ones. Further, the optimal number of fields is between 6 and 8 , so that the duration of the successive passage of all the fields coincide with the period of restoration of the vegetal carpet in order to restart the grazing on the first plot.

\section{Conclusion}

The data obtained show that it is necessary to diversify the technical functions of the aerial flight systems and especially to orient their future development to strategic areas such as agriculture.

In this context, obtaining and using descriptive information on a large scale through the drone system is very important in assessing the evolutionary dynamics of natural ecosystems. Thus, the sense of evolution of these agroecosystems can be appreciated, information on the level and quality of agricultural production can be obtained, prevention of land depreciation and especially the abandonment of agricultural surfaces thus orienting the price policy in the future and helping to elaborate future strategies at local or regional level are provided.

Acknowledgments. Gratitude to the executive of Denta ATU, Timis county for the support granted in the field stage and for making available the surface history as well as the Law 165/2013. We also appreciate the Timis Agriculture and Rural Development Agency for discussions and guidance. 


\section{References}

1. Dragomir LO, Herbei MV (2012). Monitoring The Subsidence Phenomenon In Petrosani City Using Modern Methods And Technologies. Environmental Engineering \& Management Journal (EEMJ), 11(7).

2. Govedarica M, Ristic A, Herbei MV, Sala F (2015). Object oriented image analysis in remote sensing of forest and vineyard areas. Bulletin of UASVM Cluj-Napoca, 72(2): 362-370.

3. Herbei MV, Herbei R, Smuleac L, Salagean T (2016). Using Remote Sensing Techniques in Environmental Management. Bulletin of UASVM Cluj-Napoca, 73(2), 230237.

4. Popescu CA (2015). Cadastru general - Înregistrarea sistematică a imobilelor, Editura Eurospatmpa, Timsioara.

5. Sălăgean T, Șuba EE, Pop ID, Matei F, Deak J (2019). Determining Stockpile Volumes Using Photogrammetric Methods, Scientific Papers. Series E. Land Reclamation, Earth Observation \& Surveying, Environmental Engineering. Bucuresti, ISSN 2285-6064, 8:114-119.

6. Samfira I, Popescu C (2011). Elemente metodologice aplicate in cercetarea pajistilor, Editura Mirton , Timisoara
7. Sestraș P, Bilașco Ș, Roșca $S$, Naș S, Bondrea MV, Gâlgău R, Vereș I, Sălăgean T, Spalevic V, Cîmpeanu SM (2019). Landslides Susceptibility Assessment Based on GIS Statistical Bivariate Analysis in the Hills Surrounding a Metropolitan Area, Sustainability ISSN: 2071-1050, 1-23, 11(5).

8. Sestraș $\mathrm{P}$, Bondrea MV, Cetean $\mathrm{H}$, Sălăgean $\mathrm{T}$, Bilaşco Ș, Naș S, Spalevic V, Fountas S, Cîmpeanu SM (2018). Ameliorative, Ecological and Landscape Roles of Faget Forest, Cluj-Napoca, Romania and Possibilities of Avoiding Risks Based on GIS Landslide Susceptibility Map, Notulae Botanicae Horti Agrobotanici, ISSN: 0255-965X, 46(1): 292- 300.

9. Smuleac A, Popescu CA, Herbei MV (2018). Metode moderne de achizitie si prelucrare a datelor topogeodezice, Editura Mirton, Timisoara

10. Şuba EE, Sălăgean T, Pop I, Matei F, Deak J, Coroian I, Ficior D (2017). Using Photogrammetric UAV Measurements as Support for Classical Topographical Measurements in Order to Obtain the Topographic Plan for Urban Areas, Bulletin UASVM Cluj-Napoca ISSN 1843-5254, 74(2): 197203. 